УДК 37.091.113

(C) Красін С.A., 2020 p.

UDK 37.013.8(091)

http://orsid.org/0000-0002-2042-1713

https://doi.org/10.34142/23128046.2020.48.16

C. A. Красін

\title{
РЕАЛІЗАЦІЯ ПЕДАГОГІЧНИХ УМОВ ФОРМУВАННЯ У СТУДЕНТІВ ВИЩОЇ ШКОЛИ ГОТОВНОСТІ ДО УСВІДОМЛЕНОГО БАТЬКІВСТВА
}

У статті визначено, що сім'я як первинний та основний осередок суспільства відіграє провідну роль у всебічному розвитку й вихованні підростаючого покоління, а ие забезпечує актуальність проблеми формування у студентів вищої школи готовності до усвідомленого батьківства. У представленій публікаиії визначено умови успішного здійснення иього прочесу та схарактеризовано прочес їх реалізачї на практиці. Так, перша з циих умов передбачала здійснення цілеспрямованої підготовки викладачів до формування готовності до усвідомленого батьківства студентів закладів вищої освіти. Така підготовка реалізовувалась у межах науково-методичної роботи кафедр та передбачала використання різних методів і форм ї̈ організаиї: засідання кафедри, наукові семінари, «круглі столи», лекиії, науково-практичні конферениії, вебінари, взаємовідвідування занять тощо.

Друга визначена педагогічна умова була пов'язана зі збагаченням змісту різних дисииплін навчальним матеріалом про усвідомлене батьківство. Для цього на заняттях із різних навчальних дисииплін (філософських, історичних, педагогічних, психологічних, іноземних мов) студенти засвоювали цінну з точки зору порушеної проблеми інформацію, щзо сприяло поглибленню їхніх знань про феномен усвідомленого батьківства, а також оволодівали відповідними практичними вміння та навичками під час участі в рольових та ділових іграх, тренінгах на відповідну тематику.

Реалізаиія третьої визначеної педагогічної умови вимагала надання педагогічної підтримки студентів у здійсненні ними системного самовдосконалення у визначеному напрямі. Ця умова реалізовувалась шляхом пропонування студентам підготовлених автором методичних вказівок, рекомендацій, інструктивних листів із питання вдосконалення власної готовності до усвідомленого батьківства, залучення майбутніх батьків до участі в кураторських годинах, диспутах, «мозкових штурмах», присвячених порушеній проблемі, ознайомлення студентів із різними діагностичними методами та методиками, які дозволяють людині об 'єктивно оијінтти свій стан готовності до усвідомленого батьківства та виявити основні недоліки в иіий готовності. 
Ключові слова: сім'я, батьки, усвідомлене батьківство, готовність до усвідомленого батьківства, педагогічні умови.

Krasin S. A. The implementation of pedagogical conditions of the formation of higher school students of readyness for the conscious paternity. The article defines that the family as the primary and main center of society plays a leading role in the comprehensive development and education of the younger generation, and this ensures the urgency of the problem of forming in high school students of readiness for the conscious paternity. The presented publication defines the conditions for the successful implementation of this process and describes the process of their implementation in practice. Thus, the first of these conditions provided for the purposeful training of teachers to form a readiness for the conscious paternity of the students of higher education institutions. Such training was implemented within the scientific and methodological work of teachers of departments and involved the use of various methods and forms of its organization: department meetings, scientific seminars, "round tables", lectures, scientific and practical conferences, binaries, mutual attendance and ect.

The second defined pedagogical condition was related to the enrichment of the content of various disciplines with educational material about conscious paternity. To do this, in classes in various disciplines (philosophical, historical, pedagogical, psychological, foreign languages), students learned valuable information from the point of view of the problem that contributed to deepening their knowledge of the phenomenon of conscious paternity, as well as mastering relevant practical skills during participation in role and business games, trainings on relevant topics.

The implementation of the third defined pedagogical condition required the provision of a pedagogical support to students in the implementation of their systematic self-improvement in a certain direction. This condition was realized by offering students guidelines prepared by the author, recommendations, instruction letters on improving their readiness for the conscious paternity, involving future parents in curatorial classes, debates, "brainstorming" on the problem, acquainting students with different methods and techniques that allow a person to objectively assess their state of readiness for the conscious paternity and identify the main shortcomings in this readiness.

Keywords: parents, conscious paternity, readiness for the conscious paternity, child-parent relations, pedagogical conditions.

Вступ. Сьогодні сім'я як первинний та основний осередок суспільства відіграє провідну роль у вихованні успішної й високоморальної особистості та виступає важливим чинником збереження культурної специфіки нації. Проте ця соціальна група зможе виконувати своє призначення тільки в тому випадку, коли молоді люди, які мріють створити сім’ю, демонструють стійку 
готовність до усвідомленого батьківства. Тому виникає актуальна потреба в забезпеченні цілеспрямованого формування цієї готовності в української молоді.

Як визначено, окремі аспекти цієї проблеми знаходяться в центрі уваги багатьох дослідників. Так, О. Свдокимова здійснила дослідження ціннісного ставлення до батьківства студентів (Yevdokimova, 2015). Р. Овчарова розробила програму формування психологічної готовності до материнства (Ovcharova, 2006). О. Антонович вивчала проблему формування психологічної готовності батьків до взаємостосунків із майбутньою дитиною (Antonovych, 2009). М. Срміхіна провела наукові розвідки, присвячені досліджуванню питань формування усвідомленого батьківства на основі суб'єктивно психологічних чинників (Ermikhina, 2003). О. Лемещенко вивчала соціально-психологічні умови формування у старшокласників готовності до усвідомленого батьківства (Lemeshchenko, 2016). Н. Островська визначила шляхи формування усвідомленого батьківства в діяльності територіальної громади (Ostrovska, 2014). Р. Хавула спрямував свій науковий пошук на вивчення психолого-педагогічних чинників формування психологічної готовності юнаків до батьківства (Khavulya, 2010). Л. Повалій досліджувала питання формування відповідального батьківства (Povaliy, 2015).

Проте загалом результати аналізу теорії та практики здійснення сімейного виховання свідчать, що проблема формування в молоді, зокрема у студентів, готовності до усвідомленого батьківства на гідному рівні не розв'язана, що вимагає продовження наукових розвідок у виділеному напрямі.

Мета та завдання. Основна мета роботи - проаналізувати процес реалізації визначених та теоретично обгрунтованих умов формування у студентів готовності до усвідомленого батьківства. Для цього було вирішено завдання: розкрити зміст проведеної підготовки викладачів до формування зазначеної готовності; висвітлити шляхи змістового збагачення змісту різних навчальних дисципліни навчальним матеріалом про усвідомлене батьківство; схарактеризувати педагогічну підтримку здійснення студентами систематичного самовдосконалення в указаному напрямі.

Методи дослідження. Для виконання поставленої мети й завдань використано різні теоретичні (аналіз, зіставлення, узагальнення, систематизація) та емпіричні (спостереження, тестування, анкетування, експертне оцінювання) методи, що дозволило схарактеризувати процес 
реалізації умов формування у студентів готовності до усвідомленого батьківства.

Результати. Зазначимо, що на попередньому етапі наукового пошуку було теоретично обгрунтовано педагогічні умови формування цієї готовності у студентів вищої школи (це обгрунтування було представлено в попередній авторській статті). Зокрема, було висловлено припущення, що успішність формування у студентів вищої школи готовності до усвідомленого батьківства забезпечує дотримання таких умов: 1) здійснення цілеспрямованої підготовки викладачів до формування готовності до усвідомленого батьківства студентів закладів вищої освіти; 2) забезпечення збагачення змісту різних дисциплін навчальним матеріалом про усвідомлене батьківство; 3) надання педагогічної підтримки студентам у здійсненні ними системного самовдосконалення у визначеному напрямі.

Реалізація зазначених умов відбувалась в освітньому процесі студентів 1-4 курсів Харківського національного педагогічного університету імені Г. С. Сковороди й Хмельницької гуманітарно-педагогічної академії. Проаналізуємо реалізацію кожної з названих умов.

Так, перша умова передбачає здійснення попередньої підготовки викладачів до формування у студентів готовності до усвідомленого батьківства. Зазначена підготовка реалізовувалась у межах науковометодичної роботи викладачів кафедр, які викладали різні навчальні дисципліни (філософські, історичні, педагогічні, психологічні, іноземні мови) та передбачала використання різних методів і форм іiі організації.

Зокрема, зазначена проблема неодноразово обговорювалась на наукових семінарах кафедр, на яких до відома викладачів доводилась інформація про важливість кожного 3 них зробити свій вагомий внесок у вирішення сформульованої проблеми, здійснювалось мотивування педагогів щодо цілеспрямованого формування у студентів готовності до усвідомленого батьківства. Так, організаторам освітнього процесу нагадувалось, що на початок 2020 р. в Україні функціонує більше 700 дитячих будинків, у яких проживає майже 3,5 тис. дітей. Проте, за заявою заступника міністра соціальної політики О. Коваля, уже в 2023 р. дитячі будинки планується взагалі розформувати, а воднораз вимагається підвищити ефективність роботи 3 проблемними батьками. У виключному випадку діти будуть направлятися до патронатної або прийомної сім’ї чи сімейного будинку дитини. 
Воднораз викладачам були наведені дані опитування Всеукраїнського дослідження «Громадська думка з питань насильства стосовно дітей», яке проводилося на замовлення проєкту Ради Європи «Зміцнення та захист прав дітей в Україні» в 2014 р. Згідно $з$ цими даними, майже 65 \% дітей різною мірою піддаються хоча б одному виду (психічному чи фізичному) насильству з боку батьків (2015). Очевидно, що в сучасних умовах, коли в країні суттєво загострилась економічна криза, ситуація з дітьми в сім'ях стала ще більше загрозливою. Причому навіть наявність у батька та матері вищої освіти абсолютно не є гарантією того, що вони проявляють усвідомлене ставлення до виконання своїх батьківських функцій. Тому дуже важливо, щоб викладачі у процесі роботи зі студентами приділяли увагу питанню формування в них усвідомленого батьківства.

Для успішного здійснення цього процесу питання розглядалось на засіданнях кафедри, наукових семінарах, «круглих столах», спеціально організованих лекціях («Усвідомлене батьківство як соціально-педагогічний феномен», «Види батьківства», «Структура, ознаки та суть усвідомленого батьківства», «Готовність до усвідомленого батьківства»). Значна увага приділялась обговоренню питання, як забезпечити успішне формування готовності молодих людей до усвідомленого батьківства на заняттях із різних дисциплін. Зокрема, аналізувались можливості збагачення змісту конкретних дисциплін навчальним матеріалом, пов'язаним із сімейним вихованням дитини, проводились відповідні тренінги, ділові й рольові ігри тощо. Для підвищення обізнаності членів кафедр в окресленій галузі організовувались також взаємовідвідування занять, які включали різні питання підготовки студентів до здійснення сімейного виховання. Пізніше відбувалось обговорення результатів відвіданих викладачами занять.

Особлива увага приділялася наданню допомоги викладачампочатківцям, які не мали багатого стажу педагогічної роботи, а тому відчували різні проблеми в роботі зі студентами. Цим викладачам надавалась індивідуальна підтримка у проведенні занять, на яких увага студентів акцентувалася на важливості прояву (сьогодні чи в майбутньому) кожним із них усвідомленого ставлення до виконання своїх батьківських обов'язків, зокрема проводились індивідуальні консультації з цього питання.

Крім того, викладачі, які були залучені до проведення експерименту, брали активну участь у науково-практичних конференціях, вебінарах, внутрішніх та зарубіжних стажуваннях, у тому числі з питань формування готовності студентів до усвідомленого батьківства, що дало змогу не тільки 
мотивувати педагогів до здійснення роботи зі студентами в указаному напрямі, але й підвищити рівень обізнаності з цього питання, вдосконалити необхідні вміння та навички.

Реалізація другої визначеної педагогічної умови спрямовувалась на забезпечення збагачення змісту різних дисциплін навчальним матеріалом про усвідомлене батьківство. Як було визначено, ця умова може успішно реалізуватися на заняттях 3 більшості навчальних дисциплін. Проте найбільші можливості в цьому плані мають гуманітарні дисципліни, які викладаються майбутнім фахівцям різного профілю, зокрема: філософські, історичні, соціологічні, психологічні й педагогічні. Тому в експериментальній діяльності зазначена умова реалізовувалась саме під час вивчення студентами названих вище дисциплін.

Так, викладання різних тем 3 філософії доповнювалось начальним матеріалом, пов'язаним із сімейним вихованням. Наприклад, під час вивчення студентами теми «Філософія стародавнього світу» вони знайомились 3 цікавою інформацією про сприйняття античними філософами сімейних стосунків як моделі політичних відносин, про основні права жінок у сім’ї в різних стародавніх державах (Спарта, Аттика, Стародавній Рим тощо). Під час викладання теми «Філософія Середньовіччя» студентам пояснювалось, що, з одного боку, саме в епоху Середньовіччя жінка зі знатної родини набувала ореол «прекрасної дами», а, з іншого, - вона часто ставала жертвою насильства з боку свого чоловіка.

Викладачі також підкреслювали, що в багатьох стародавніх держав можливість отримання слабким немовлям права на життя залежала від милосердного рішення його батька, що в ті часи дітей часто били, причому тілесні покарання сприймались як спосіб спокутування маленькою людиною первородного гріха людства через власні страждання та водночас як засіб вироблення в дитини звички беззаперечно підкорятися старшим, терпляче переносити життєві негаразди. Також конкретизувалося, що зміст сімейного виховання та права дитини переважною мірою залежали від належності іi родини до певної верстви населення.

Загалом викладачі філософії підсумовували, що в епоху Античності й Середньовіччя, 3 одного боку, визнавалась необхідність домашнього виховання як важливого фактору формування в майбутньому гідних громадян держави. 3 іншого боку, положення дитини в давніх сім'ях було принизливим, бо іiї сприймали як нижчу істоту. Тому жорстокі побиття, 
моріння голодом, знущання над дітьми вважалось нормою для тогочасного сімейного виховання.

Особлива увага викладачів щодо формування готовності студентів до усвідомленого батьківства приділялась під час викладання навчальних дисциплін психолого-педагогічного циклу. Зокрема, у процесі вивчення майбутніми фахівцями різних модулів («Загальні основи педагогіки. Теорія виховання», «Теорія i технологія цілісного педагогічного процесу», «Особистість у діяльності та спілкуванні», «Сім'я як об’єкт соціальнопедагогічної діяльності» тощо) вони активно засвоювали знання про: суть сім’і та усвідомленого батьківства; роль родини в розвитку й особистісному становленні дитини; основні функції сім’ї та обов’язки батьків, види батьківства, основні методи, форми, засоби, стилі сімейного виховання; значення батьківського авторитету тощо.

Під час проведення практичних занять 3 психолого-педагогічних дисциплін застосовувались різні методи, форми, техніки роботи, спрямовані на формування готовності студентів до усвідомленого батьківства. Зокрема, 3 цією метою використовувались: рольові ігри, спрямовані на виконання («проживання») студентами різних ролей дитини та батьків; вправи, тренінги, пов’язані з осмисленням основних сімейних цінностей («Цінності нашої сім'ї», «Спогади дитинства», «Батьківська сім'я»), здійсненням самооцінювання («Мідні труби», «Моє батьківське (материнське) Я», «Світ батьків», «Я - батько (мати)»), формуванням комунікативних навичок («Глас в пустелі», «Подарунок», «Похвала») і навичок емпатії («Світ очами дитини», «Проєктивний малюнок», «Тандем»), розвитком емоційної сфери («Три плани», «Відлуння», «Сіамські близнюки», «Вираз почуттів»), створенням позитивного емоційного тла («Світлина», «Очі в очі», «Зустріч емоцій», «Веселка», «Театр кабукі», «Мандрівник»), підвищенням рівня мотивації («Минуле - сьогодні - майбутнє», «Моя майбутня дитина», «Моє життя через П’ять років», «Моя сім'я») тощо.

Реалізація третьої педагогічної умови була спрямована на спонукання студентів до здійснення систематичного самовиховання. Ця умова впроваджувалась шляхом опрацювання студентами підготовлених автором методичних вказівок із самовдосконалення готовності до усвідомленого батьківства, рекомендацій 3 організації сімейного виховання на основі виявлення батьками відповідального ставлення до виконання своїх батьківських обов'язків та функцій, інструктивних листів із питання 
оволодіння студентами знаннями, уміннями, якостями як складниками готовності до усвідомленого батьківства.

Майбутні батьки також залучались до участі в кураторських годинах, диспутах, «мозкових штурмах», присвячених порушеній проблемі. Зокрема, для підвищення ефективності самоосвітньої й самовиховної діяльності студентів 3 оволодіння готовністю до усвідомленого батьківства вони опрацьовували підготовлені матеріали, в яких розкривалась суть батьківства як динамічної структури, здатної до змін під впливом таких факторів: досвід життя у власній батьківській сім’; вплив інформаційного простору, в якому функціонують телебачення, інтернет, соціальні мережі, інформаційні канали тощо; соціальні й моральні норми суспільства; спілкування з однолітками та їх погляди на батьківство; статеві відносини i, як наслідок, можлива запланована чи незапланована вагітність; кохання та пошук шлюбного партнера тощо.

Спонукання студентів до систематичної діяльності 3 оволодіння готовністю до усвідомленого батьківства передбачало приділення їхньої уваги опануванню всіх складників цього особистісного феномену. Так, мотиваційний складник цієї роботи забезпечувався спонуканням молодих людей до усвідомлення власного бажання мати дитину та стати гарними батьками, сумлінно виконувати свої батьківські функції, а також до розуміння своїх потреб i спонукань як члена сім’ї. Для забезпечення когнітивного складника зазначеної готовності майбутні батьки реалізовували самоосвітню діяльність, спрямовану на: поглиблення знань щодо фізичного і психічного розвитку дитини на різних вікових етапах; отримання знань про особливості взаємодії 3 дитиною, іiі потреби та можливості; знання про відповідальну поведінку батьків стосовно дитини та один до одного; розуміння про розподіл відповідальності у виховання дитини між батьками тощо.

Емоційний складник усвідомленого батьківства студентів реалізовувався шляхом актуалізації оцінно-ціннісних ставлень до себе як до майбутніх батьків, позитивного сприйняття майбутнього батьківства, себе як матір чи батько для дитини, розподілу сімейних ролей тощо. Засвоєння поведінкового складника зазначеної готовності студентів було спрямовано ними на оволодіння необхідними для батьків особистісними якостями, уміннями і навичками, здійснення виховання дитини та піклування про неї, гуманістичну взаємодію 3 дитиною та іншими членами сім’ї, а також на формування навичок контролю своїх дій і поведінки. 
Слід також зазначити, що під час надання педагогічної підтримки студентам у здійсненні ними системного самовдосконалення у визначеному напрямі відбувалось ознайомлення їх з різними діагностичними методами та методиками, які дозволяють людині об'єктивно оцінити свій стан готовності до усвідомленого батьківства та виявити основні недоліки в цій готовності.

Обговорення. Отже, порівнюючи отримані результати з результатами досліджень інших науковців, можемо зазначити, що визначені педагогічні умови формування готовності до усвідомленого батьківства студентів закладів вищої освіти не були предметом вивчення науковців, чиї пошуки були більш зорієнтовані на розробку технологій формування інших аспектів готовності студентів до здійснення сімейного виховання. Авторські доробки й висновки не суперечать висновкам інших науковців, які проводили наукові розвідки в галузі деяких суміжних проблем, а доповнюють їх.

Висновки. У статті визначено, що ефективність формування готовності до усвідомленого батьківства студентів закладів вищої педагогічної освіти підвищується за таких педагогічних умов: 1) здійснення цілеспрямованої підготовки викладачів до формування готовності до усвідомленого батьківства студентів закладів вищої освіти; 2) забезпечення збагачення змісту різних дисциплін навчальним матеріалом про усвідомлене батьківство; 3) надання педагогічної підтримки студентам у здійсненні ними системного самовдосконалення у визначеному напрямі, а також представлено перебіг реалізації цих умов на практиці.

У майбутньому планується описати процедуру діагностики динаміки в стані готовності студентів до усвідомленого батьківства та іiі кінцеві результати, що дозволить сформулювати висновок про правильність сформульованого в дослідженні припущення.

\section{ЛІТЕРАТУРА:}

Антонович О.С. Формирование психологической готовности родителей к взаимоотношению с будущим ребенком : дис. ...канд. психол. наук : 19.00.07. Самара, 2009. $250 \mathrm{c}$.

Евдокимова Е. В. Формирование ценностного отношения к родительству у студентов вуза : дис. ... канд. психол. наук : 19.00.07. Пятигорск, 2015. 211 с.

Ермихина М. О. Формирование осознанного родительства на основе субъективнопсихологических факторов : дис. ...канд. психол. наук : 19.00.07. Казань, 2004. $249 \mathrm{c}$.

Лемещенко О. Р. Соціально-психологічні умови формування у старшокласників готовності до усвідомленого батьківства: дис. ...канд. психол. наук : 19.00.05. Сєвєродонецьк, 2016. 224 с.

Овчарова Р. В. Родительство как психологический феномен : учебное пособие. М. : Московский психолого-социальный институт, 2006. 496 с. 
Островська Н. О. Формування усвідомленого батьківства молоді в діяльності територіальної громади : дис. ...канд. пед. наук : 13.00.05. Слов’янськ, 2014. 347 с.

Повалій Л. В. Формування у старшокласників відповідального батьківства як сімейної цінності. Young Scientist. 2015. № 2 (17). С. 291-294.

Хавула Р. М. Психолого-педагогічні чинники формування психологічної готовності юнаків до батьківства. Проблеми сучасної психології : зб. наук. пр. Кам'янець Подільського національного університету імені Івана Огієнка, Інституту психології ім. Г.С. Костюка АПН України. Кам’янець Подільський : Аксіома, 2010. № 10. C. $771-781$

Результати опитування громадської думки з питань насильства стосовно дітей (грудень 2014 - травень 2015): дані Всеукраїнського дослідження «Громадська думка 3 питань насильства стосовно дітей», проведеного на замовлення проекту Ради Європи «Зміцнення та захист прав дітей в Україні». Режим доступу : http://www.kiis.com.ua/materials/pr/20152905_children/presentation_children\%206\%20 28.05.pdf

\section{REFERENCES:}

Antonovich O. S. (2009) Formirovanie psihologicheskoj gotovnosti roditelej k vzaimootnosheniyu s budushim rebenkom [The formation of psychological readiness of parents for the relationship with the future child] : dis. ...kand. psihol. nauk : 19.00.07. Samara (in Russian).

Ermihina M. O. (2004) Formirovanie osoznannogo roditelstva na osnove subektivnopsihologicheskih faktorov [The formation of conscious paternity on the basis of subjective and psychological factors] : dis. ...kand. psihol. nauk : 19.00.07. Kazan. (in Russian).

Evdokimova E. V. (2015) Formirovanie cennostnogo otnosheniya k roditelstvu u studentov vuza [The formation of a value attitude to the paternity among the university students] : dis. ... kand. psihol. nauk : 19.00.07. Pyatigorsk. (in Russian).

Havula R. M. (2010) Psihologo-pedagogichni chinniki formuvannya psihologichnoyi gotovnosti yunakiv do batkivstva. Problemi suchasnoyi psihologiyi [Psychological and pedagogical factors of the formation of psychological readiness of young men for parenthood] : $\mathrm{zb}$. nauk. pr. Kam'yanec Podilskogo nacionalnogo universitetu imeni Ivana Ogiyenka, Institutu psihologiyi im. G.S. Kostyuka APN Ukrayini. Kam'yanec Podilskij : Aksioma. 10. S. 771-781. (in Ukranian).

Lemeshenko O. R. (2016) Socialno-psihologichni umovi formuvannya u starshoklasnikiv gotovnosti do usvidomlenogo batkivstva [Socio-psychological conditions for the formation of high school students' readiness for the conscious paternity] : dis. ...kand. psihol. nauk : 19.00.05. Syevyerodoneck. (in Ukranian).

Ostrovska N. O. (2014) Formuvannya usvidomlenogo batkivstva molodi v diyalnosti teritorialnoyi gromadi [The formation of conscious paternity of youth in the activities of the territorial community] : dis. ...kand. ped. nauk : 13.00.05. Slov'yansk. (in Ukranian).

Ovcharova R. V. (2006) Roditelstvo kak psihologicheskij fenomen [Paternity as a psychological phenomenon]: uchebnoe posobie. M. : Moskovskij psihologo-socialnyj institut. (in Russian).

Povalij L. V. (2015) Formuvannya u starshoklasnikiv vidpovidalnogo batkivstva yak simejnoyi cinnosti [The formation of responsible paternity as a family value in high school students]. Young Scientist. 2 (17). S. 291-294. (in Ukranian).

Rezultati opituvannya gromadskoyi dumki z pitan nasilstva stosovno ditej [The results of a public opinion poll on violence against children] (gruden 2014 - traven 2015): dani Vseukrayinskogo doslidzhennya «Gromadska dumka z pitan nasilstva stosovno ditej», 
provedenogo na zamovlennya proektu Radi Yevropi «Zmicnennya ta zahist prav ditej $\mathrm{v}$ Ukrayini». Retrieved from

http://www.kiis.com.ua/materials/pr/20152905_children/presentation_children\%206\%20 28.05.pdf. (in Ukranian).

\begin{tabular}{ll}
\hline \multicolumn{1}{c}{ Інформація про авторів: } & \multicolumn{1}{c}{ Information about the authors: } \\
Красін Сергій Анатолійович: & Krasin Sergii Anatolievich \\
ORCID: 0000-0002-2042-1713 & ORCID: 0000-0002-2042-1713 \\
аспірант кафедри педагогіки, Харківський & A postgraduate student of the Department of \\
національний педагогічний університет ім. & Pedagogy, Kharkiv National Pedagogical \\
Г. С. Сковороди, вул. Валентинівська, 2, м. & University named after G.S. Skovoroda, \\
Харків, Україна, 61000. & Valentinovskaya street, 2, Kharkiv, Kharkiv \\
e-mail: icdp.org.ua@gmail.com & region, 61000 \\
& E-mail: icdp.org.ua@ gmail.com
\end{tabular}

Цитуйте цю статтю як: Красін С.А. Реалізація педагогічних умов формування у студентів вищої школи готовності до усвідомленого батьківства. Теорія та методика навчання та виховання. 2020. № 48. С. 172-182.

DOI: https://doi.org/10.34142/23128046.2020.48.16

Дата надходження статті до редакції:

Стаття прийнята до друку: 